\title{
The Peter Redpath Museum, An Architectural Analysis
}

by

\author{
Rhodri W. Liscombe
}

The Redpath Museum enjoys the distinction of having been one of the first Canadian buildings singled out for praise in the international architectural literature. Commissioned in 1880 by that notable benefactor of McGill, Peter Redpath, and marking the 25th anniversary of Sir William Dawson's appointment as Principal, the Museum was designed by A. C. Hutchison and A. D. Steele. They conceived an idiosyncratic expression of eclectic Victorian Classicism, synthesizing ancient and modern as well as European and North American sources to dignify the campus and express the significance of its purpose.

Le musée Redpath a l'honneur insigne d'avoir été l'un des premiers édifices canadiens à mériter les éloges de la littérature architecturale internationale. Commandé en 1880 par le célèbre bienfaiteur de McGill, Peter Redpath, et marquant le $25^{\mathrm{e}}$ anniversaire de la nomination de Sir William Dawson au poste de principal de l'Université, le musée a été conçu par A. C. Hutchison et A. D. Steele. Ces deux architectes ont opté pour une expression idiosyncratique du classicisme victorien éclectique, conjugant dans cet édifice l'ancien et le moderne ainsi que l'influence européenne et nord-américaine pour donner de la dignité au campus et témoigner de l'importance de sa mission.

The Redpath Museum of McGill University commands attention as an unusual and late example of the Greek Revival in North America (Figure 5). ${ }^{1}$ It also possesses an historical significance beyond its stylistic idiosyncrasies as the first specifically designed museum of natural science in Canada as well as being the initial building in a monumental architectural scheme for the University. Furthermore, it was one of only two Canadian buildings singled out for illustration in the third, revised edition of James Fergusson's pioneering if arbitrary international study of post-Renaissance architecture, The History of the Modern Styles of Architecture, completed by Robert Kerr in 1891 .

The Museum was commissioned early in 1880 by Peter Redpath. The first reference to the project in the Minutes of the Board of Governors of McGill University occurs on 27 March:

The Governors have heard with greatest gratification the announcement by $\mathrm{Mr}$. Peter Redpath of his intention to erect and complete a Museum for the University for the safekeeping of the collections of the University in Geology, Mineralogy, Palaentology, Zoology, Botany and Archaeology. ${ }^{2}$

Redpath had amassed a considerable fortune as a sugar refiner in Montreal and expended a significant proportion upon the expansion of the University, establishing a Chair in Mathematics and later financing erection of the University Library, built in a Richardsonian Romanesque style to the designs 

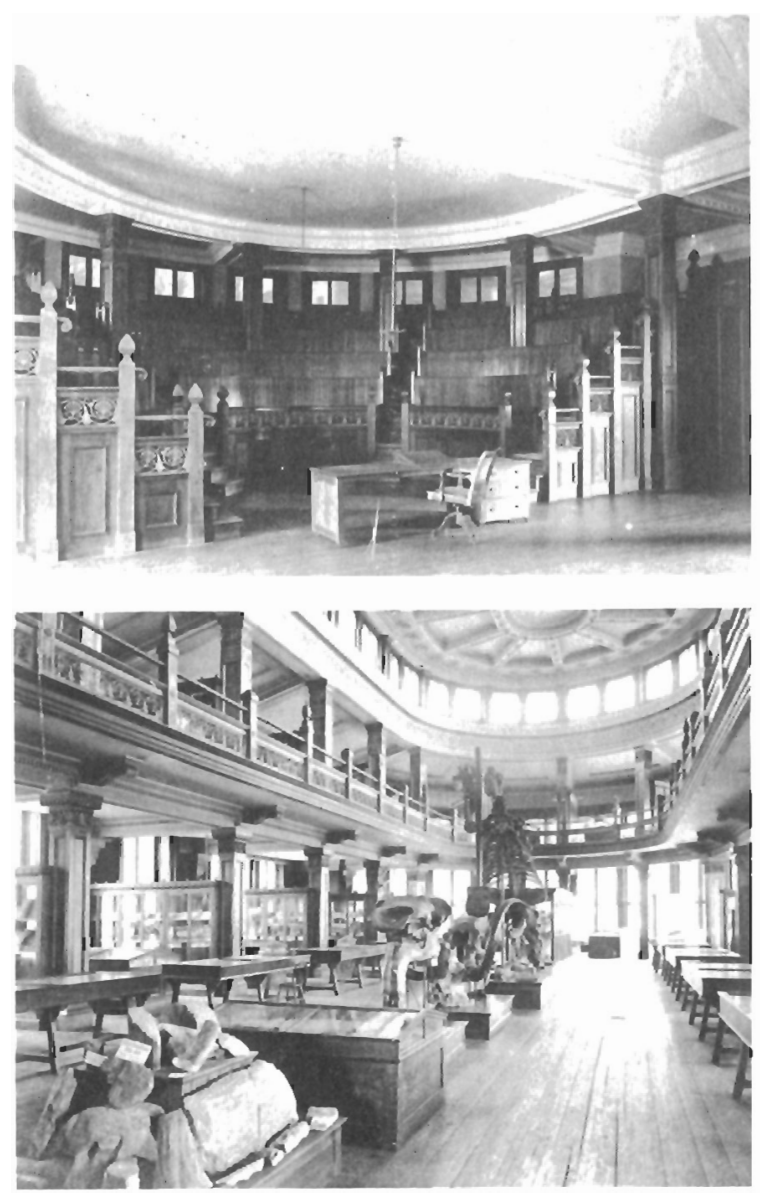

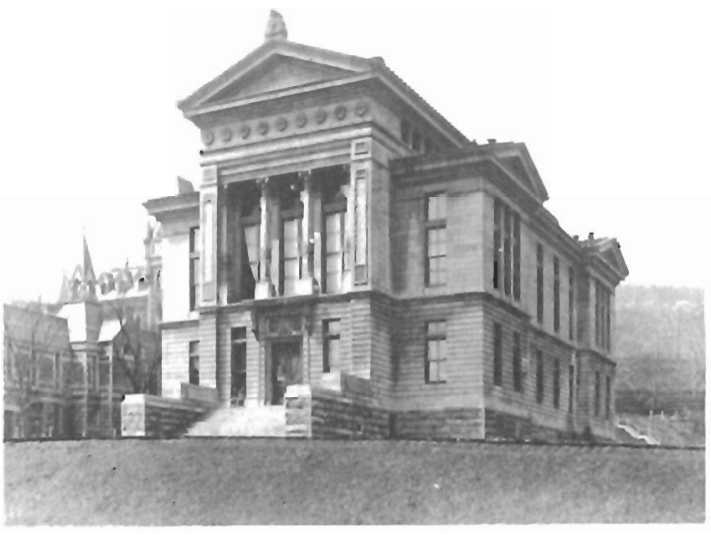

THE PETER REDPATH MUSEUM

McGILL UNIVERSITY
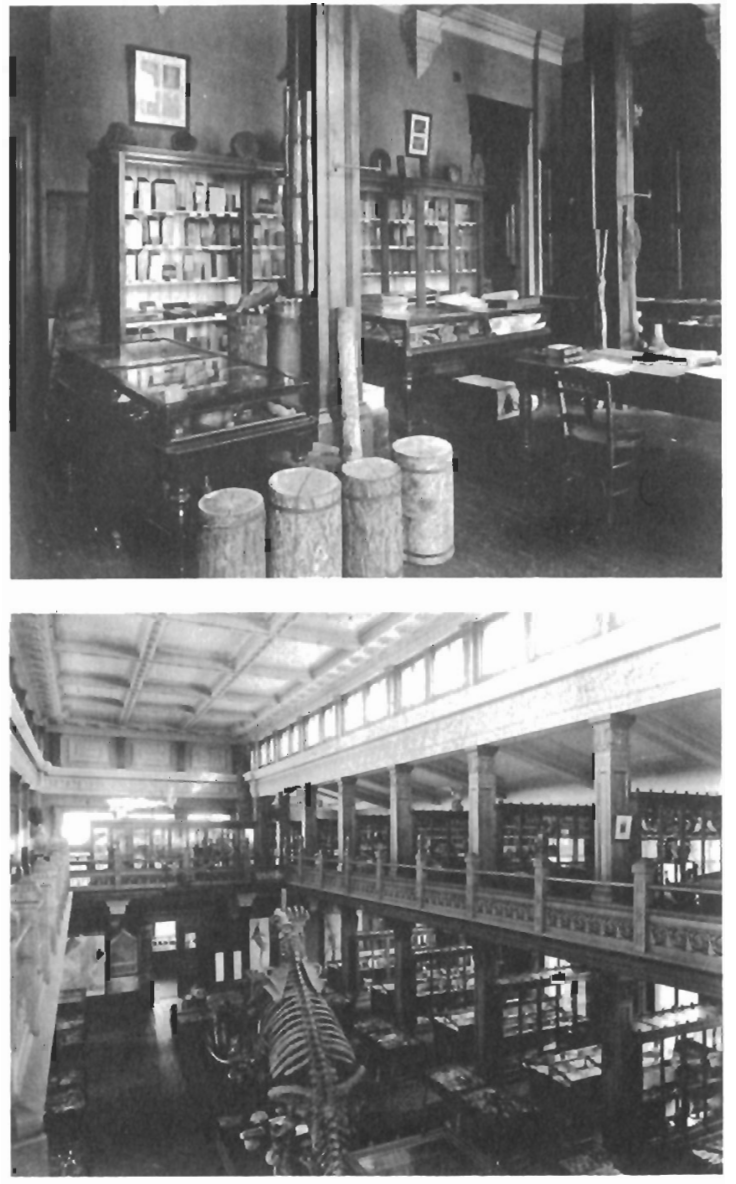

Fig. 5. The Peter Redpath Museum, McGill University. (Courtesy of Notman Photographic Archives) 
of Taylor and Gordon between 1891 and 1893, as well as providing some $\$ 100,000$ for the construction and endowment of the Museum. ${ }^{3}$

His generosity in regard to the Museum was inspired by admiration for Sir William Dawson, the Principal of the University, who, shared with him a love and knowledge of British culture and learning. In addition, Dawson, along with Dr. Philip Carpenter, had assembled most of the collections to be housed there. Thus it was appropriate that Redpath should have publicly announced his decision to commission the Museum at a banquet held on 2 April 1880 to celebrate the twenty-fifth anniversary of Dawson's appointment ${ }^{4}$ and that Dawson should have been so concerned with the building's design and construction. Construction began a short time after 24 April, when the Estate Committee recommended that "the Museum to be erected by $\mathrm{Mr}$. Redpath be placed in front of the William Molson Hall, and in the space between the line of same and the Presbyterian College and at the head of open space reserved for a Cricket Ground." 5 The foundation stone was laid on 21 September by the Governor General, the Marquis of Lorne, who anticipated that the building would be "a new temple of the practical science." ${ }^{6}$ That judgement was amplified in the speech delivered by the chancellor, the Honourable Charles Day, upon the occasion of the formal opening of the Museum on 24 August 1882, which coincided with that of the annual meeting of the American Association of the Advancement of Science convoked at McGill:

The architectural beauty of this edifice in which we are assembled -- its classic design -- the elegance and completeness of its finish, make it in itself an education of no small value; while joined to these excellencies, its ample proportions and perfect adaptation to its destined uses indicate the munificence of its founder. ${ }^{7}$

Redpath was closely involved in the commission. He it was who chose the local architects, A. C. Hutchison and A. D. Steele. They had been in partnership since 1875 and were the best qualified of the Montreal architects whom Dawson wished to support. Alexander Cooper Hutchison (1838-1922) was a Canadian of Scottish parentage, which might explain his joining with Steele who, apparently, had emigrated from Scotland in $1875^{\circ}$ The first record of Steele in Montreal is an entry in Lovell's Montreal Directory for that year, showing that he was in partnership with Hutchison. Steel retired due to ill-health in 1890 and died in 1891.

Hutchison's career, by contrast, is reasonably well documented. His father was a prominent Montreal contractor to whom Alexander became apprenticed as a stone cutter. In 1858 Alexander was engaged to supervise the stone work on Christ Church Cathedral, Montreal, which was being built to the designs of Frank Wills. Between about 1860 and 1862 he moved to Ottawa to undertake a similar function on the East Block of the new Parliament Buildings. Upon his return to Montreal he entered the office of the architect, Springle, and later went into practice on his own. In 1870 he was invited to prepare designs with H. M. Perrault for the new City Hall, erected in a simplified Second Empire style. This was the earliest of a number of important local commercial and ecclesiastical commissions in which Hutchison displayed a competent eclecticism, ranging from the neoRenaissance of the Royal Insurance Building, Place d'Armes, begun in 1880 
and extended up to 1902 (demolished); the Richardsonian Romanesque of the Erskine Church, Sherbrooke Street, circa 1893; the Beaux-Arts of the London Liverpool and Globe Insurance Building, Place d'Armes, circa 1902 (with Wood) and the Canadian Express Building, McGill Street, circa 1907 (with Wood); and the Italian Romanesque of St. Andrew's Westmount of 1908 (with Wood and Miller, demolished). During the early period of his career he also gave courses on architectural drawing at the Mechanics Institute and for the Montreal Board of Arts and Manufactures; and he later worked for the promotion of professional training and standards as President and Secretary of the Quebec Association of Architects, and was instrumental in the creation of the School of Architecture at McGill. His reputation was such by 1880 that he was appointed a founding member of the Royal Canadian Academy by the Lord Lorne and commissioned by one of the richest Montrealers, Donald A. Smith, later created Baron Strathcona for his services to the Canadian Pacific Railway, to build a large residence, multifarious in stylistic inspiration, on Dorchester Street.

To return to the Redpath Museum, Hutchison in collaboration with Steele produced a design that synthesizes motifs from a remarkably wide range of ancient and modern, European and North American sources, with a licence that borders on solecism. Indeed some of the detailing, and particulary the awkward and anti-classical break between the architraves of the Orders on the main and side facades, rather conflicts with Chancellor Day's encomium.

The least conventional features appear on the entrance front. That is dominated by an antis portico, seldom adopted for monumental structures by Greek Revival architects either in the United States or Europe, although there were examples in Quebec City and Montreal. It comprises two columns flanked by two half-pilasters of an hybrid Corinthian Order recessed behind piers with plaques and banding. The capitals and the foliate and honeysuckle ornament on the lower register of the shafts are as far removed from their ancient Greek origins as the form of the portico is from such precedents as the Treasury of the Athenians at Delphi. Further, the wide inter-columnation and the slender proportions of the columns contrast with the excessively large dimensions of the entablature of the pediment. The disharmonious effect is pointed up by the prominence of the decoration on the shafts, the lumpish paterae upon the frieze, and the positioning of the columns directly, as it appears, on the thin lintel above the doorway.

Some precedent for the upper part of the composition can be found in the coarsely worked rock tombs of Ionia, three of which, including the Lycian Tomb, were illustrated by James Fergusson in the first part of his History of Ancient and Mediaeval Architecture, originally published in $1855 .^{9}$

The portico is also raised on an unusually high basement of one and a half storeys and flanked by two anta or pilaster porticoes set at ninety degrees to the facade. The arrangement of the porticoes, aside from their elevation on tall basements, compares with that employed by James Gallier Senior for the City Hall at New Orleans, 1845-1850. This offers a more probable source than the obscure late Roman or Carolingian church, sometimes called the Temple of Clitumnus, located near the hamlet of Pissignano in the region of Spoleto which, nonetheless, has a similar portico composition. ${ }^{10}$ 
The incised ornament of the pilasters and antae of the side and rear facades recalls another American source, namely the 'modern' Greek articulation on designs published by Asher Benjamin in The Architect: or Practical Home Carpenter (Boston, 1830). Of particular relevance are the incised quasi-Greek patterns on Benjamin's schemes for a doorway, plate 28 , and for a fireplace, plate 50, which Hutchison and Steele, seemingly, have transformed into a kind of substitute fluting on the antae in the side porticoes and semi-circular projection at the rear. Above this motif they have added three small round incisions that are possibly intended to represent a capital and which were, perhaps, suggested by the end sections of the classical guttae; such novel decorations reappear on the internal pilasters of the Museum and on the balusters of the main staircase.

The liberal use of antae on the exterior and the geometrical massing are more reminiscent of British and German Greek Revival architecture. The influence of the European Revival upon the architects is supported by circumstantial evidence, beyond the availability to them of engravings and photographs, not least in the first two editions of Fergusson's Modern Styles, 1862 and 1873. It is possible that Steele had visited Glasgow and Edinburgh before emigrating to Canada and had seen Alexander Thomson's United Presbyterian Church, Caledonia Road, Glasgow, 1856-1857, remarkable for its long run of antae on the side facades, and William Playfair's Royal Scottish Academy, Edinburgh, 1822-1835, which comprised a colonnade of Greek Doric columns flanked by two projecting porticoes not unlike the general composition of the side elevations of the Redpath; Playfair's Surgeons Hall, Edinburgh, 1829-1832, also had an elevated Ionic portico framed by two anta porticoes at ninety degrees to it, but of the same height. In that city was also Thomas Hamilton's Royal High School, begun in 1825, the main portico of which was raised on a high basement.

On the other hand, even if Steele were not familiar with these buildings, Dawson and Redpath would have been. Dawson reported that Redpath had encouraged the architects to study the designs of the major European museums, the predominantly Greek style of which could explain Hutchison and Steele's choice of, or a version of, the style at such a late date. Of course, both Dawson and Redpath visited Britain regularly and were familiar with its architecture. One other factor in the selection of the style that should be noticed here is the Neo-Classical style of the Arts Building, replete with a Greek Doric portico, completed before 1875 and situated behind and to the east of the Museum. The semi-circular rear facade of the Redpath suggests that the architects had seen illustrations of August Stüler and Heinrich Strack's National Gallery in Berlin, 1865-1867, although the form had been combined with the Greek Orders in one of the most celebrated English examples of the Revival, Harvey Lonsdale Elmes's St. George's Hall, Liverpool, begun in 1842. Their appreciation of German NeoClassical architecture is further indicated by the similarities that exist between the Museum and Karl Friedrich Schinkel's Schauspielhaus, Berlin, 1819, whereon the main portico is raised on a tall rusticated basement, flanked by subsidiary porticoes set at right angles to it and the exterior articulated by antae.

The rear facade of the Redpath Museum is the clearest external statement of the architects' attention to the functional requirements of the 
commission, affording ample illumination to the exhibition space on the two upper floors and accommodation for a lecture theatre seating two hundred on the first floor. The specifications were related in the retrospective account of the commission given by Dawson in his short biography of Redpath:

It is planned in such a manner as to have the largest possible amount of well lighted space within, and, for its size, is one of the best museum buildings anywhere. It is not intended for a large general collection but for a series of typical specimens for teaching purposes in all departments of Natural Science; and to render these as accessible as possible, both for the use of individual students and for demonstration by professors and lecturers to large classes. ${ }^{11}$

The provision of good internal lighting almost certainly led the architects to concentrate the exhibition space on the second and third floors, above those assigned to teaching and to the preparation of exhibits. This explains the adoption of a high basement, marked on the exterior by channelled rustication, while the volume of specified accommodation and the confined dimensions of the ground plan -- the main body measures only 133 by some 60 feet -- offer one reason for the elongated vertical proportions of the 'piano nobile' and, in particular, those of the architrave of the main portico.

The semi-circular projection may have been introduced after the acceptance of a preliminary design, since the Canadian Architecture Collection at McGill includes a comparable scheme to that built, but on which the rear facade is flat. The scheme is recorded in two elevations, one inscribed "Front Elevation" (though no entrance door is shown) and the other in a different hand "Redpath Museum Side Elevation," and in one transverse section inscribed only "Redpath Museum." This last corresponds with the internal arrangements of the executed Museum, excepting the absence of a gallery at the upper level. Similarly, the elevations carry the main features of the articulation of the present building, notably the raised Order, the antis form of the main portico, the projection of the porticoes flanking the entrance and the two storey windows and clerestorey on the side facades. They differ, however, in having three less decorated columns in the main portico, rustication on the 'piano nobile' and only one portico on each side capped by an attic rather than by a pediment. Nevertheless, these divergences are less considerable than those which exist between the two elevations and the elevation Hutchison presented to the National Gallery of Canada about 1882 as his diploma piece for the Royal Canadian Academy showing proposed extensions to the University including a Faculty of Applied Science building ${ }^{12}$. This unexecuted design, submitted while the Redpath Museum was under construction, has a three tier portico of two columns and antae which produces a somewhat more conventionally proportioned feature on the upper storey. The deep architrave and attic of the preliminary scheme for the Museum and of the facade as built have become a separate floor which is illuminated by single windows rather than by a continuous clerestorey. The fenestration on the side facades also comprises separate openings on each floor and it is noticeable that in this project the internal divisions are more clearly expressed upon the exterior. In addition one minor detail tends to confirm the foregoing chronological analysis, the antifixa which ornaments the apex of the pediment of the main portico of the Museum 
recalls those above the corner piers in the preliminary scheme.

The internal arrangements of the upper floors of the Museum as originally constructed have remained largely intact. The second floor consists of an open hall behind the landing of the staircase. The hall contains show cases disposed centrally and between the windows and the wood-sheathed square columns that support the third floor and its gallery, a device to secure further space without excessive loss of light. The core of the columns is of cast iron, the material employed for the beams of the upper storey, while the main structure is built of limestone from the Trenton formation near Montreal and erected on a rubble foundation. At the opening of the Museum the collections of Archaeology, Fossils, Minerals, Rocks and Palaeontology were displayed on the second floor, and those of Zoology, Molluscae and Ornithology on the third. Both floors are reached by the main staircase which rises from the basement through the subsidiary portico on the east side and passes through the vestibule behind the entrance. Typical of the architects' untrammelled attitude towards Classical architecture, the capitals of the two columns in the vestibule invert the usual pattern of the Ionic Order, having their volutes pointed upwards. As well as the lecture theatre, the first floor at first accommodated a professor's office, a classroom, an herbarium and a reference library, while the basement, situated just below the true ground level, housed storage and preparation rooms, a residence for the janitor and two furnaces "with a special arrangement of hot air chambers for ventilation."13

Beyond serving an immediate educational purpose, Redpath and Dawson hoped that the building of the Museum would mark the first phase in a major expansion of the University. The architecture of McGill then comprised the present Arts Building, completed by the amalgamation of earlier structures in 1862, an Observatory, begun in 1863, and the first Medical Building, constructed in 1872.14 Dawson told the distinguished assembly gathered to watch the laying of the foundation stone:

I could wish to see a building similar to this for our Faculty of Applied Science, on the other side of our grounds; I could wish to see a Senate House and Dining Hall of still more stately proportions; I could wish to see our physical apparatus and class rooms as well provided for as our natural sciences collection;.... We cannot hope to secure all these things at once, but may venture to anticipate that the foundation of the Peter Redpath Museum may stimulate other friends of education to provide like liberal aids for all these and other portions of education work.... In connection with this I have pleasure in stating that A. C. Hutchison, Esq., one of the architects of the Peter Redpath Museum, proposes to prepare a plan and elevation showing how the buildings required in the future for the above and other University purposes may be erected in due relation to the present building, and in harmony with the plan of the new Museum. ${ }^{15}$

Part of his address was a reference to Hutchison's R. C. A. diploma elevation inscribed The McGill University. Sadly the "liberal aids" were not forthcoming to realise Hutchison's project; but he later collaborated in the design and construction of the McGill University Union, 1905 (now the 
McCord Museum) and Macdonald College, Ste. Anne de Bellevue, $1906 .^{16}$

Hutchison's diploma design continues the themes first developed for the Redpath Museum. The antis portico is now articulated with both round and square columns and grouped in two and three storey compositions. The antae are used to unify the whole ensemble and the more complex facades of the imposing central structure. The convocation Hall and what might have been intended for a library in the east wing of that building are articulated with semi-circular projections. The proposed buildings are also liberally provided with incised decoration. The novel constituent is the square pavilions which lend to the main building a sense of Palladian tripartite facade composition. However, the sharply defined massing and severe articulation of the pavilions again suggest the influence of the German Greek Revivalists and especially that of Schinkel whose Schloss Tegel built near Berlin in 1822 had comparable corner pavilions. The result of the aggrandizement of the vocabulary of the Museum is to inflate its uncertainties of syntax, particularly in the centre section of the main building. Its pavilions and porticoes compress motifs from the framing architecture and thus display the same mixture of academism and licence.

The presence of such contrasting aesthetic characteristics in the design of the Redpath Museum was recognised by Kerr, who, in 1891, substantially revised the text of Fergusson's Modern Styles. Kerr selected the Museum and Thomas Fuller's Neo-Gothic Parliamentary Library, Ottawa, 1859-1877, as the best examples of the "good modern work" that had been erected in Canada in the second half of the century. Of the former he wrote, it "represents very fairly a sufficiently graceful treatment of the Classic -- indeed of the NeoGrec, although scarcely French in form [a passing reference to the Gallic culture of Quebec] -- on somewhat academical ground. The reader will find several indications in this design of that kind of independent thought which is characteristically American." 17 The critique is one of many instances of Kerr's condoning historicist architecture and expressing admiration for contemporary North American design which differed markedly from the views Fergusson had given in the first and second editions of his book. For Kerr not only brought the text up to date by adding a quantity of new material, but also questioned Fergusson's radical and critical analysis of nineteenth century architecture in Europe and North America. ${ }^{18}$ The future of North American architecture was then, in his opinion, assured. By way of proof, he summoned no less a personage than the British Liberal Prime Minister, William Ewart Gladstone, who had pronounced that North America would supplant Europe in the "march of civilization". ${ }^{19}$

The Redpath Museum, independent in style, practical in plan, and a synthesis of North American and European sources, was evidence of that prophetic statement.

\section{Notes}

1. The author wishes to thank Professors John Bland and Peter Collins (deceased) of the Department of Architecture and Dr. Faith Wallis formerly of the Archives of McGill University for their help and advice during the 
preparation of this article.

A brief history of the Museum appears in $\mathrm{R}$. Traquair, The Buildings of McGill University (Montreal, 1925) not paginated. The identification of the style of the Museum as Neo-Greek first occurred in Sir J. W. Dawson, In Memoriam: Peter Redpath (Montreal, 1894); in the Montreal Society of Architecture's guide book Exploring Montreal (Montreal, 1974) 118 it is described as Egyptian Revival.

2. The Board of Governors [of the Royal Institution for the Advancement of Learning] had no part in the commission other than the selection of the site, as quoted in the text.

3. The most useful biography is Dawson, In Memoriam: Peter Redpath (see note 1), which also contains a history of the building of the Museum, pp. 17-26. Further personal information appears in The Canadian Album. Men of Canada (Montreal, 1893) III: 301, with photograph. Redpath's endowment for the Museum is recorded in the Special Donation and Endowment Ledger (Record Group 100/5/3/2) and includes the following: "this small building erected on the College Grounds was presented to the University by Peter Redpath Esq., as per deed passed before Wm. B. S. Reddy, N. P., dated 24th August 1882," together with notice of a payment of $\$ 100,000$. The Dawson Papers at McGill include correspondence between himself and Redpath which confirms the fact that the benefactor paid the bills personally, though no details of payments are accounted.

4. Dawson, In Memoriam: Peter Redpath. 20 (see note 1).

5. The Reports of the Estate Committee are given in the Minutes of the Board of Governors.

6. Dawson, In Memoriam: Peter Redpath. 26 (see note 1).

7. Report on the Peter Redpath Museum of McGill University (Montreal, 1883) II: 3.

8. Biographical information on Steele kindly supplied by Professor Bland; Hutchison's career is described in the obituary printed in the Montreal Gazette, 2 June 1922, which adds two buildings not listed in the text: Crescent Street Presbyterian Church, 1878 (demolished) and extensions to the Birks Building, Union Street, 1907 and 1909 (with Wood). A shorter biography appears in the Canadian Album (Montreal, 1893) II: 172, with a poor photograph. Hutchison expressed some of his views on architecture in a speech delivered to the Quebec Association of Architects, which is quoted in part in the Canadian Architect and Builder, VI (1893): 104.

9. Reprinted in 1893 as the first volume of A History of Architecture in all Countries from the Earliest Times to the Present (London) 237, illus. 121.

10. For this curious structure, probably unknown to the architects, though it was drawn by Palladio, among others, see M. Salvi, La Basilica di San Salvatore di Spoleto (Florence, 1951) $40 \mathrm{ff}$. and plate 39-41. 
11. Dawson, In Memoriam: Peter Redpath. 17 (see note 1).

12. National Gallery of Canada, no. 235 , the drawing measures $247 / 8^{\prime \prime} \mathrm{x}$ $59 "$.

13. Dawson, In Memoriam: Peter Redpath. 17 (see note 1).

14. Traquair, Buildings of McGill University (see note 1).

15. Dawson, In Memoriam: Peter Redpath. 23 (see note 1). In a footnote to page 21 he stated that Redpath had asked the "architects" to prepare a design for a "facade of buildings in line with the Museum, so that its position might work in with any future extension, whether by a corresponding building on the east side or by a great central block and two wings."

16. Traquair, Buildings of McGill University (see note 1). Hutchison was a consultant in the former and partnered by Wood in the latter.

17. J. Fergusson, The History of the Modern Styles of Architecture, ed. R. Kerr (London, 1891) II: 170, illus. 219s. Canadian architecture was reviewed with that of Australia in a chapter entitled "British Colonial Architecture," 170-177. On page 171 Kerr wrote, "Numerous interesting examples might of course be given of good modern work in Canada, but these two will suffice to satisfy the reader of the superior quality of the best of it."

18. Fergusson's views are examined in Sir N. Pevsner, Some Architectural Writers of the Nineteenth Century (Oxford, 1972) 238-251 and those of Kerr on pages 217-221. This also contains biographical material, supplemented in the case of Fergusson by W. H. White in an essay titled "James Fergusson: A Sketch of his Life" published as a preface to the 1891 edition of the Modern Styles xxvii-xxxvii (see note 17). Fergusson (1808-1886) was a gifted amateur architectural historian, more given to philosophical generalization than was Kerr (1823-1904) who taught from 1861 as Professor of the Arts of Construction at King's College, London, and practiced as architect of Bear Wood, Berkshire, 1865-1871, notable for its eclectic style. For this house and a short biography see M. Girouard, The Victorian Country House (Oxford, 1971) 121-124 and 199.

19. Fergusson, Modern Styles, II: 373 (see note 17), from a chapter entitled "The Future of American Architecture" wherein he predicted that architecture in the United States would follow the English manner for "ages to come" excepting the influence of "the extensive use of Timber; the unsophisticated character of the landscape and environment; the natural ingenuity, self sufficiency and desire for invention of the American people; their haste of business and the influence of traditions other than English." 